\title{
KONTRIBUSI ULAMA PEREMPUAN DALAM PERKEMBANGAN ISLAM DI NUSANTARA
}

\author{
Ida Zahara Adibah \\ idazaharaadibah@gmail.com \\ Fakultas Agama Islam Universitas Darul Ulum Islamic Centre Sudirman GUPPI
}

DOI:10.21580/wa.v6i2.5695

\begin{abstract}
The discourse concerning about women's participation in the Islam's development has been occuring since the establishment of this religion, or when Prophet Muhammad was still alive. In Indonesia, the significant role of women clerics could not be more negated in the proliferation and the development of Islam. Nonetheless, our history, in some certain degrees, did not give them the decent acknowledgement, although they were assuredly appropriate to get this. Instead, the women clerics had often been questioned about their role wether it was exactly true or not, and again, were underestimated. This article aspires to briefly uphold the role of Indonesian women clerics in the development of Islam across archipelago. It would utilise the historical approach to reveal their important contribution with their own knowledge, experience, and behavior.
\end{abstract}

Keywords: Woemn, Clerics, Islam's Development

\begin{abstract}
Abstrak
Diskursus tentang keikutsertaan perempuan dalam dakwah Islam sudah terjadi pada masa awal agama ini berdiri, yaitu sejak Nabi Muhammad masih hidup. Di dalam perkembangan Islam di Indonesia sendiri, keberadaan ulama perempuan tidak dapat dinegasikan andilnya yang begitu signifikan. Namun, penulisan sejarah kita masih kurang memberikan ruang yang luas untuk peran perempuan dalam perkembangan Islam di Nusantara ini. Peran perempuan dalam masyarakat dipertanyakan tentang siapa dan apa benar bahwa itu wanita. Makalah ini secara singkat mencoba mengangkat peran tokoh-tokoh perempuan Indonesia yang mempunyai kadar keulamaan dalam perkembangan islam di Nusantara. Penelitian ini menggunakan pendekatan sejarah dalam mengungkap peran keulamaan dari beberapa sudut pandang keilmuan, pengalaman dan akhlak yang dimilikinya.
\end{abstract}




\section{Kata kunci: Perempuan, Ulama, Perkembangan Islam}

\section{A. Pendahuluan}

Pemaknaan ulama melekat dalam beberapa kualifikasi, yakni kapasitas keilmuan, pengalaman, dan akhlak. Kapasitas keilmuan mencakup latar belakang keilmuan berasal dari pesantren, penguasaan kitab kuning, wawasan luas, dan layak menjadi rujukan dalam mengambil keputusan. Sedang aspek pengamalan meliputi fungsi-fungsi sosial dalam hal penyatuan umat dan pengayom, dan konsisten. Pada aspek akhlak penekanannya pada kharisma, tawadhu', jujur dan amanah. ${ }^{1}$

Azyumardi Azra dalam Jajat Burhanudin, ${ }^{2}$ pada mulanya istilah ulama secara sederhana berarti orang yang mengetahui atau orang yang memiliki ilmu. Tidak ada pembatasan ilmu spesifik dalam pengertian ini. Tetapi seiring dengan perkembangan dan terbentuknya ilmu-ilmu Islam, khususnya fiqh pengertian ulama menjadi menyempit menjadi yang menguasai ilmu agama khususnya fiqh. Adapun dalam makalah ini yang dimaksud ulama perempuan bukan berarti perempuan yang hanya menguasai ilmu agama khusnya fiqh saja, melainkan juga mengetahui ilmu-ilmu yang lain sesuai dengan spesifikasi keilmuannya dalam rangka membantu dakwah perkembangan Islam di Nusantara. Disini faktor religio-sosiologis menjadi sangat penting. Di lingkungan masyarakat muslim Indonesia, seseorang baru benar-benar dikatakan sebagaui ulama jika telah diakui oleh komunitas mereka, baik dari sisi keilmuannya agama maupun umum, akhlaknya, kepedulian terhadap masyarakat dan mau untuk memperjuangkan Islam.

Sebagaimana dimaklumi bahwa kedudukan perempuan dalam masyarakat Islam merupakan cermin eksistensi Islam. Bilamana masyarakat Islam berjaya, maka kedudukan wanitapun akan ikut berjaya. Sebaliknya, jika Islam dalam masyarakat itu terancam dan berada di bawah tekanan, maka kondisi kehidupan kaum perempuannya mengalami hal demikian. Dalam beberapa aspek penting, perempuan ideal muslim sama dengan kaum prianya. Mereka sederhana, saleh, dan menyayangi keluarga. Sebagaimana telah disinggung, Islam memberikan sejumlah hak bagi kaum perempuan yang semula terkebiri pada masa pra Islam, antara lain untuk memperoleh pendidikan, untuk menerima warisan (yang semula hanya dijadikan obyek warisan), dan hak untuk menceraikan suami (melalui cara khulu') atau yang dalam Kompilasi Hukum Islam Indonesia pihak perempuan diberikan hak untuk mengajukan gugat cerai. ${ }^{3}$

Perkembangan Islam di Indonesia tidak lepas dari kontribusi ulama perempuan yang telah ikut menyebarkan Islam lewat jalur perdagangan, politik, perkawinan, tasawuf dan pendidikan. Islamisasi yang terjadi di Nusantara merupakan proses yang sangat

\footnotetext{
${ }^{1}$ Ahmad, Abd.Kadir, Ulama Bugis, Makassar: Indobis Publishing, 2009, hal. 177-361

${ }^{2}$ Azyumardi Azra, Biografi Sosial-Intelektual Ulama Perempuan: Pemberdayaan Historiografi dalam Jajat Burhanudin, Ulama Perempuan Indonesia, Jakarta: PT Gramedia Pustaka Utama, 2002, hal.xxvii

${ }^{3}$ Munawir Haris, Kepemimpinan Perempuan Dalam Islam, Jurnal Studi Keislaman,2015, Volume 15, Nomor 1, Juni, hal. 59
} 
penting, karena Islam yang berkembang di Nusantara tidak hanya menjadi sebuah sistem kepercayaan saja, tetapi juga telah berkembang sedemikian rupa menjadi sebuah tata pemerintahan yang menjelma menjadi kerajaan atau kesultanan yang menggunakan Islam sebagai landasan ideologi. Islamisasi di Indonesia tidak dapat dipisahkan dari peran orangorang yang telah berjasa dalam menyebarkan Islam. Munculnya para tokoh perempuan dengan berbagai latar belakang keilmuan dan aktivitasnya telah menunjukkan kiprah dan peran kaum perempuan Indonesia dalam memacu dan mendorong perkembangan Islam di Nusantara.

\section{B. Pembahasan}

\section{Potret ulama perempuan di masa awal perkembangan Islam}

Sebutan ulama dalam banyak komunitas muslim selama ini hanya ditujukan kepada kaum laki-laki dan tidak untuk perempuan. Untuk menyebut perempuan sebagai ulama harus ditambahkan ulama perempuan atau perempuan ulama. Kenyataan ini jelas memperlihatkan bahwa kaum perempuan dianggap tidak ada yang layak disebut ulama. Dengan kata lain, mereka dianggap tidak memiliki kapasitas intelektual, keilmuan, moral, dan keahlian yang lain. Ini fakta peradaban patriarkis yang telah berlangsung berabad-abad lamanya. Perempuan dalam peradaban ini sangat jarang, kalau tidak dikatakan terlarang, untuk berada pada posisi pengambil keputusan, mengelaborasi, dan mengimplementasikan hukum-hukum agama. Disamping hak-hak yang telah diberikan kepada perempuan tadi, seorang perempuan mempunyai peran penting dalam mempengaruhi keputusan-keputusan atau kebijakan publik masyarakat Islam. Di antara mereka adalah Khadijah, Fathimah, Aisyah dan lain-lain. Mereka dipandang sebagai perempuan yang mempunyai kapasitas tertentu dan ideal. Pendapat dan pemikirannya sejajar dengan pendapat dan pemikiran kaum laki-laki. Mereka mempunyai kedudukan penting dalam masa awal perkembangan Islam.

Banyak peran yang dimainkan kaum perempuan pada posisi subordinat. Khadijah adalah orang yang memeluk Islam pertama kali di era perjuangan Rasulullah SAW. Khadijah adalah sosok istri Nabi ideal yang mempunyai peranan penting atas perkembangan Islam. Kiprahnya tidak diragukan lagi. Hampir seluruh tindakan yang dilakukan oleh nabi Muhammad SAW terlebih dahulu dikonsultasikan dengan Khadijah. Peran Aisyah dalam perang Jamal sebagai pemimpin pasukan bersenjata, dan sebagai seniman terkemuka serta pengarang besar (dalam katagori sosio historis kedua dan ketiga). Kaum muslimin di dunia mengetahui bahwa perempuan paling cerdas dan ulama terkemuka adalah Aisyah. Beliau merawikan kurang lebih 1.210 hadits dan 300 diantaranya telah dirawikan secara bersama dengan Bukhari, malah tak jarang diberi ruang oleh nabi untuk memutus perkara-perkara ummat. selain beliau, sejumlah perempuan yang juga ulama di antaranya Ummu Salamah binti Abu Sofyan, Fatimah binti Qois, Amrah binti Abd Rahman (w.716 M) yang pandangannya dikenal kritis dan sering menyalahi 
pandangan laki-laki pada masanya. Hafsah binti Sirin yang dikenal zuhud dan menguasai ilmu tafsir. ${ }^{4}$

Terminologi ulama dalam konteks kebudayan Indonessia adalah gelar yang diberikan kepada orang-orang yang dipandang mengerti dan memhami ilmu-ilmu agama Islam. Ulama juga menjadi agen perubahan sosial. Hal itu biasanya dibuktikan dengan kemampuan seseorang membaca Al-Quran dan kitab-kitab kuning. Dengan keahliannya dalam keilmuan agama tersebut, ulama juga sering dipahami sebagai pemimpin atau tokoh agama. Dalam bacaan antropologis yang sederhana, ulama di Indonesia biasanya tampil dengan pakaian sarung, peci, sorban, atau tutup kepala yang lain. Tutup kepala ini, konon, merupakan ciri yang meneguhkan sosoknya sebagai ulama. Tanpa aksesori ini, unsur kehormatan (wira'i) pada diri ulama menjadi berkurang. Ulama juga dikesankan sebagai orang yang rajin beribadah, banyak membaca Al Qu'ran, berzikir, dan pandai berdoa. Mereka menjadi rujukan dalam setiap urusan yang berkaitan dengan agama, termasuk memberi fatwa. Terminologi tersebut tentu saja telah mereduksi makna genuine dari ulama. Terlepas dari perdebatan terminologis di atas, bagaimanapun ulama mempunyai kedudukan istimewa di tengah masyarakat. Menurut Al Qu'ran, ulama adalah orang-orang yang paling dekat dengan Tuhan. Merekalah orang yang paling takut kepada-Nya, sebagaimana bunyi Al Qu'ran: "Innama yakhsya Allah min 'ibadihi al-ulama." (QS Fatir [35]: 28). Ayat ini ingin menegaskan, bahwa ulama adalah mereka yang hati dan pikirannya senantiasa mengingat Tuhan.

\section{Ulama Perempuan di Panggung Sejarah Nusantara}

Berkembangnya Islam sebagai sistem kepercayaan yang kemudian menjelma menjadi sebuah ideologi dalam sistem pemerintahan tidak lepas dari peran orang-orang yang berjasa dalam menyebarkan Islam. Akan tetapi, selama ini titik tekan tentang siapa yang berperan dalam masa transisi antara Hindu Budha dengan masa Islam masih cenderung pada peran laki-laki sebagai pusat. Padahal perempuan mempunyai peran yang penting pada masa Islamisasi dengan status sosial yang dimiliki. Ini disebabkan rekonstruksi sejarah kita bercorak androsentris, karena sejarah terpusat pada kegiatan kaum laki-laki. ${ }^{5}$

Perempuan menghilang dari literatur sejarah Indonesia. Dalam berbagai kajian, perempuan kadang dikatakan berperan penting, tetapi bahasannya tidak terlihat. Dari segi jumlah saja, lebih dari 1.700 buku mengenai sejarah yang diterbitkan di Indonesia sejak tahun 1997, hanya 2 persen yang membahas peran perempuan. Itupun belum dalam tinjauan yang lebih berkeadilan ${ }^{6}$. Berikut ini peran ulama perempuan yang terlibat memberikan kontribusi dalam perkembangan Islam di Nusantara dengan berbagai profesi dan peran yang digelutinya.

\footnotetext{
${ }^{4}$ Ilyas, husnul fahimah, Jurnal Al-Quran, 2018, volume 24 no 2 Desember, hal. 1

${ }^{5}$ Kuntowijoyo, Metodologi Sejarah, Yogjakarta; Tiara Wacana, 1994, hal. 99

${ }^{6}$ Maria Hartiningsih, Perspektif Historiografi Feminis dalam Penulisan Sejarah, makalah disampaikan pada lokakarya Historiografi Indonesia di Yogjakarta yang diselenggarakan oleh Pusat Studi Asia Tenggara, UGM, Senin 30 Juli 2007
} 


\section{Putri Campa dan Putri Cina}

Pada abad XV di Jawa dikenal beberapa tokoh wanita yang memiliki peran penting dalam Islamisasi. Kedua wanita tersebut berdasarkan kisah-kisah tradisional merupakan istri dari raja terakhir Majapahit yang bergelar Brawijaya IV yang memerintah antara tahun 1468-1478 M. kedua tokoh wanita tersebut diperkirakan telah menganut agama Islam. Hal ini dibuktikan dengan adanya kisah seperti yang ditulis dalam Serat Kandha yang menyatakan bahwa Putri Campa dimakamkan secara Islam. Menurut H. J De Graff dan Th. G.Th. Pigeaud ${ }^{7}$ yang dimaksud dengan Campa dalam tambo-tambo Islam Jawa adalah kawasan di pantai Timur Hindia belakang, (daerah Laos saat ini). Pendapat ini didukung oleh J.J Ras ${ }^{8}$ yang menyatakan bahwa daerah Campa yang dimaksud adalah daerah yang sekarang dikenal sebagai Vietnam Selatan. Pendapat kedua ini diperkuat oleh dukungan dari sastra sejarah baik dari Melayu maupun Jawa, bahwa pada mulanya Campa merupakan wilayah yang dipengaruhi oleh agama Hindu dan Budha. Peran Putri Campa dalam Islamisasi adalah sebagai pembuka jaringan terhadap tokoh-tokoh penyebar agama Islam, terutama kaitannya dengan pemberian suatu wilayah bagi tokoh-tokoh tertentu. Status Purti Campa (Dwarawati) sebagai istri Brawijaya telah membuka kesempatan yang lebih luas bagi Raden Rahmad untuk mendirikan pusat pendidikan karena ada jaminan dari raja?.

Tokoh wanita lain yang dianalisis perannya dalam Islamisasi Jawa adalah Putri Cina. Walaupun dari katagori yang sama, peran Putri Cina dengan Putri Campa, meski keduanya sama-sama istri dari Brawijaya, Putri Cina tidak dapat memberikan jaminan dan akses langsung kepada tokoh-tokoh penyebar agama Islam. Peran Putri Cina lebih cenderung genealogis atau menurunkan pemimpin atau tokoh penyebar Islam. Hal ini karena Putri Cina adalah ibu dari Raden Patah sebagai pemimpin pertama kekuasaan Islam di Jawa. Sementara itu Putri Cina adalah ibu dari Raden Patah dan Raden Timbal. Raden Patah dalam perkembangannya kemudian menjadi penguasa Islam pertama di Pulau Jawa. Kedua tokoh wanita tersebut memiliki kaitan dengan tokoh-tokoh sentral dalam Islamisasi di Jawa, yakni Wali Sanga. Kedua tokoh wanita tersebut telah meretas jalan sekaligus menjadi katalis pada masa transisi antara pengaruh Hindu-Budha dan Islam di Jawa pada abad XIV-XV ${ }^{10}$. Walaupun hanya memiliki peran pada aspek genelaogis, tidak mengurangi peran penting Putri Cina dalam transisi dari masa Hindu -Budha ke masa Islam. Dalam perkembangannya, Raden Patah berhasil mendapatkan pengakuan sebagai pemimpin di kawasan Bintara oleh raja karena aspek keturunan. Hal ini tidak lain karena adanya hubungan genealogis antara raja dengan Raden Patah sebagai anaknya dari Putri Cina.

7 De Graff, H.J. dan Th.G.Th.Pigeaud, Kerajaan-Kerajaan Islam Pertama di Jawa: Kajian Sejarah Politik Abad ke-15 dan ke-16. Terjemahan, Jakarta: Grafitipers, 1985, hal. 22

${ }^{8}$ Ras, J.J. Tradisi Jawa mengenai Masuknya Islam di Indonesia, dalam Stokhof, W.A.L., dan Kaptein N.J.G(ed), Beberapa Kajian Indonesia dnan Islam, Kumpulan Karangan, Jakarta: INIS, 1980, hal. 125

9 Tsabit Azinar Ahmad, Peran Wanita Dalam Islamisasi Jawa pada Abad XV, Jurnal Paramita Volume 21, Nomor 1- Januari, 2011, hal. 11

${ }^{10}$ Tsabit Azinar Ahmad, Peran Wanita Dalam Islamisasi Jawa pada Abad XV, Jurnal Paramita Volume 21, Nomor 1- Januari, 2011, hal. 7 


\section{Teungku Biru}

Menurut catatan sejarah bahwa ada seorang ulama perempuan, namanya Datu Beru yang berprofesi sebagai hakim. Datu Beru yang berasal dari kerajaan Linge (Kabupaten Aceh Tengah sekarang), saat itu kerajaan Linge diperintah oleh raja ke 16 bertepatan pada masa Sulthan Alaudin Ri'ayatsyah al-Qahhar 9 1537-1571. Suatu waktu terjadi Raja Linge terbukti membunuh adik tirinya, sehingga oleh Qadhi Malikul Adil (hakum Agung kesultanan) raja tersebut dijatuhi hukum membayar diyat 100 ekor kerbau yang kemudian dibayarkan kepada saudara tirinya serta ibu tirinya yang masih hidup. Dalam proses peradilan tersebut Datu Beru terlibat aktif sebagai hakim. ${ }^{11}$

Namun demikian sayang sekali, sampai saat ini belum banyak tulisan baik berupa buku ataupun karya lain yang secara khusus membahas lebih jauh tentang latar belakang dan sejarah hidup Datu Beru. Padahal tokoh tersebut ada dalam realitas sejarah, sebuah kenyataan historis yang patut disesalkan. Karena ia termasuk ulama perempuan dalam kapasitasnya sebagai seorang hakim, tentunya ia memiliki ilmu yang cukup dalam mengenai masalah hakim, tentunya juga memiliki ilmu yang cukup dalam mengenai masalah syariat Islam. Hal juga membuktikan bahwa pada masa lalu perempuan Aceh telah berperan dalam ranah publik tanpa ada kendala sosial, budaya dan agama. Tidak dapat disangkal bahwa Datu Beru adalah seorang ulama perempuan yang memberikan kontribusi secara intelektual pada masyarakat dataran Tinggi Gayo. Hal ini dapat disimpulkan bahwa meskipun tidak mendirikan lembaga pendidikan tetapi ia mampu menjadi sosok yang menginspirasi masyarakat pada masanya terutama dalam ilmu fiqh atau hukum Islam. ${ }^{12}$

\section{Teungku Fakinah.}

Selain Teungku Biru, tokoh perempuan yang masih sangat terkenal adalah Teungku Fakinah (1856-1933). Teungku Fakinah bukan saja seorang ulama perempuan pendidik, tetapi juga seorang panglima perang yang mampu mempengaruhi rakyat menentang Belanda (Nurjanah, 2004: 30). ${ }^{13}$ Semenjak kecil Fakinah telah belajar dari orang tuanya, ibunya mengajari baca-tulis huruf Arab, mengajar membaca al-Qur'an dan ilmu-ilmu agama dalam bahasa Melayu. Disamping itu, ia juga diajarkan fiqih (hukum Islam), tasawuf, akhlak, sejarah, tafsir, hadis dan lain-lain.

Fakinah memulai kiprahnya dalam bidang pendidikan dengan membangun Dayah Lam Beunot di Mukim Lam Krak. Fakinah bersama dengan suami Teungku Ahmad mengembangkan Dayah tersebut yang dibiayai oleh mertuanya, selanjutnya ia membangun Dayah yang diberi nama Dayah Lamdiran, pembangunan Dayah ini bermula dari sebuah musyawarah pada tahun 1911 seusai turun dari gerilya menuju gampongnya di daerah Lam

\footnotetext{
${ }^{11}$ Al Yasa' Abubakar, Syariat Islam di Propinsi Aceh Paradigma Kebijakan dan kegiatan, Banda Aceh: Dinas syari'at Propinsi Nangroe Aceh Darussalam, 2005, hal. 389-390

12 Sri Astuti A. Samad, 2016, Peran Perempuan dalam Perkembangan Pendidikan Islam di Aceh ( kajian Terhadap Kontribusi Wanita dalam Tinjauan Sejarah), Jurnal Al-Maiyyah, Volume 9 No. 2 juliDesember, 2016, hal. 189

${ }^{13}$ Nurjanah Ismail, Teungku Fakinah; Profil Ulama dan Pejuan Wanita Aceh, dalam Tim Penulis IAIN Ar-Raniry, Ensikolopedi Pemikiran Ulama Aceh, Banda Aceh: Ar-Raniry Press, 2004, hal. 189
} 
Krak. Setelah mengadakan perundingan dengan Tuanku Raja Kemala dan Teuku Panglima Polem Muhammad Daud, maka Teungku Fakinah membangun kembali Dayahnya yang telah porak poranda selama musim perang. Dalam waktu relatif singkat Dayah lamdran berkembang menjadi pusat pendidikan Islam yang cukup maju saat itu. Santrinya tidak hanya terdiri dari kaum perempuan, tetapi juga kaum pria yang berasal dari seluruh Aceh. ${ }^{14}$

Untuk memperdalam ilmu agamanya, Teungku Fakinah bersama dengan suaminya yang juga seorang ulama,Teungku Ibrahim pergi ke Makkah pada tahun 1915 menunaikan haji dan bermukim di sana selama 4 tahun sambil terus belajar. Selama di Timur Tengah ia banyak berjumpa dengan ulama dan terpengaruh dengan gerakan Wahabiah juga pembaharuan yang dipimpin oleh Jamaluddin al- Afghani bersama muridnya Muhammad Abduh. Kemudian tahun 1018 kembali ke Aceh seorang diri karena suaminya berpulang ke rahmatullah. Dengan tekat yang kuat ia memimpin Dayah Lamdiran dan melakukan perubahan dan reformasi dalam bidang Pendidikan Dayah. ${ }^{15}$

Besarnya penghargaan dan penghormatan kawan maupun lawan kepada pahlawan dan pendidik perempuan maka diabadikan menjadi jalan Teungku Fatimah. Diantara murid-mirid perempuan yang kemudian menjadi ulama dan mengajar, yaitu: Teungku Fatimah Bate Linterung, Teungku Sa'adah Lamjane, Teungku Fathimah Ulee Tutue, dan Teungku Hawa Lamdilip. Pendidik, ulama dan pahlawan besar Teungku Fakinah wafat pada tanggal 3 Oktober 1933 dan dimakamkam dalam kompleks Dayah Lamdiran Kabupaten Aceh besar. Untuk mengabadikan jasa besarnya di Banda Aceh namanya dijadikan sebagai nama salah satu rumah sakit di Banda Aceh.

\section{Fatimah, Perempuan Pengarang Kitab Kuning dari Banjar}

Nama Fatimah binti Abdul Wahab Bugis boleh jadi tidak terlalu dikenal di kalangan ulama Melayu-Nusantara, namun tokoh ulama perempuan ini sering disebutsebut sebagai penulis kitab Parukunan Melayu, sebuah kitab kuning dengan aksara ArabMelayu (Jawi) yang banyak dipelajari di hampir seluruh Melayu-Indonesia. ${ }^{16}$ Fatimah dilahirkan di Martapura, Kalimantan Selatan, dari keluarga terdidik. Fatimah binti Abdul Wahab banyak mewarisi ilmu-ilmu keislaman dari bapaknya yang merupakan ulama besar dan ternama. ${ }^{17}$ Lebih jauh, kehadiran Fatimah diakui telah menjadi perintis bagi emansipasi kaum perempuan di bidang pendidikan. Keterlibatan Fatimah dalam tradisi keulamaan dan keilmuan Islam dikenal Lewat karyanya, kitab Parukunan Melayu.

${ }^{14}$ Sri Astuti A. Samad, Peran Perempuan dalam Perkembangan Pendidikan Islam di Aceh ( kajian Terhadap Kontribusi Wanita dalam Tinjauan Sejarah), Jurnal Al-Maiyyah, Volume 9 No. 2 juli- Desember, 2016, hal.198

15 Nurjanah Ismail, Teungku Fakinah; Profil Ulama dan Pejuan Wanita Aceh, dalam Tim Penulis IAIN Ar-Raniry, Ensikolopedi Pemikiran Ulama Aceh, Banda Aceh: Ar-Raniry Press, 2004, hal. 44

${ }^{16}$ Zuhairini et al, Sejarah Pendidikan Islam, Jakarta: Bumi Aksara, 2008, hal. 144

17 Zulfa Jamalie dan Syaiful Hadi, Mengungkap Riwayat Peranan Fatimah binti Abdul Wahab Bugis dalam sejarah Pendidikan Perempuan di Kalimantan, Al-Banjari, voume 8, nomor 2, Juli, 2009, hal. 120 
Kitab ini sederhana saja, sesuai dengan namanya Parukunan, berarti uraian dasar mengenai rukun Islam dan Iman, dalam istilah Banjar disebut dengan rukun-marukun. Walaupun sederhana, kitab ini merupakan salah satu yang paling populer di antara kitabkitab yang sejenis, dan sering dicetak kembali. Kalau dilihat dari segi kitab parukunan Jamaluddin tak jauh berbeda dengan kitab sejenis lainya. Namun yang menarik, kitab ini tidak menyinggung sisi fiqh klasik yang kini dianggap diskriminatif terhadap perempuan. Pengarang tidak meletakkan perempuan pada posisis rendah dari pada laki-laki. Ia menghindari dari perkara yang sangat membedakan antara kedua jenis kelamin, seperti aqiqah, warisan, dan kesaksian. Secara garis besar pemikiran Fatimah binti Abdul Wahhab Bugis yang termuat dalam kitab Parukunan Melayu dapat dibedakan menjadi dua bagian, yakni pemikirannya dibidang tauhid dan fiqh. Sejauh ini kitab parukunan memang memuat pengetahuan dasar dan syariah, dan hanya sedikit meyediakan ruang diskusi menyangkut teori-teori yang mendukung praktik-praktik itu. ${ }^{18}$

Keberadaan Fatimah sebagai penulis kitab Parukunan menunjukkan bahwa sejak abad ke 19, penguasaan ilmu-ilmu agama tidak hanya terbatas dikalangan laki-laki saja, tetapi juga perempuan, khususnya dimasyarakat Banjar. Sekarang ini, kitab parukunan masih beredar luas dan tetap di pergunakan oleh masyarakat terutama di kalangan Muslim tradisional. Fatimah binti Abdul Wahab bugis diperkirakan wafat tahun 1828 dalam usia 53 tahun.

\section{Siti Walidah}

Nyai Siti Walidah adalah nama asli dari seorang perempuan inspiratif dimasanya yang telah berhasil menggerakkan perempuan Muhammadiyah saat itu. Nyai Siti walidah istri dari Ahmad Dahlan lahir di kauman yogjakarta pada tahun 1872 M. Putri dari Kyai haji Muhammad Fadlil, seorang ulama dan anggota Kesultanan Yogjakarta. Ibunya dikenal dengan nama Nyai Mas. Siti walidah dibesarkan di lingkungan agamis tradisional. ${ }^{19}$ Siti Walidah kecil bersekolah di rumah, diajarkan berbagai aspek tentang Islam, bahasa Arab dan Quran, membaca Al-Qur'an dalam naskah Jawa. Sejak kecil, kemampuan berdakwahnya sudah mulai diasah, sehingga dipercaya ayahnya untuk membantu mengajar di langgar kiai Fadhil. Siti Walidah menikah pada tahun 1889 dengan Muhammad Darwis atau lebih dikenal dengan Kyai Haji Ahmad Dahlan. Siti Walidah selalu mendampingi perjalanan suaminya dalam mendirikan Muhammadiyah pada tahun $1912 \mathrm{M}^{20}$

Melalui Aisyiyah, ${ }^{21}$ Siti Walidah mendirikan sekolah-sekolah putri dan asrama, serta keaksaraan dan program pendidikan Islam bagi perempuan. Dengan Catur Pusat pendidikan yaitu pendidikan di rumah, pendidikan di sekolah, pendidikan di masyarakat

\footnotetext{
${ }^{18}$ Suaidi Asyhari, Nalar Politik NU dan Muhammadiyah: Over Crossing Java Sentris, terj. Mohamad Rapik, Yogjakarta: LKis, 2010, hal. 89

${ }_{19}$ Yunus Anis, Riwayat Hidup Nyai Ahmad Dablan Ibu Muhammadiyah dan Aisyiyah Pelopor Pergerakan Indonesia, Jogjakarta: Yayasan Mercusuar, 1968, hal. 8

${ }^{20}$ Dian Ardiyani, Konsep Pendidikan Perempuan Siti Walidah, Tajdida, Vol 15, No.1, Juni, Surakart: UMS, 2017, hal. 14

${ }^{21}$ Suratmin, Nyai Ahmad Dahlan (Proyek Inventarisasi dan Dokumentasi Sejarah Nasional), Jakarta, 1981, hal. 62-63
} 
dan pendidikan di tempat-tempat ibadah. Siti Walidah memulai gerakan ini dengan pendidikan pengajian bagi kaum perempuan di Kauman. Kegiatan ini diisi dengn kegiatan kursus Al-Quran yang diperuntukkan gadis-gadis kauman yang masuk sekolah netral. Di samping belajar tentang agama, forum pengajian juga mengajarkan mereka cara menulis dan membaca, pengajian ini dinamakan Maghribi School karena jam diadakannya pengajian setelah Maghrib. Disamping itu masih ada media dakwah pengajian yang lain yaitu Sopo Tresno, dan Wal Asri. ${ }^{22}$ Yang menarik adalah ketika Siti Walidah mampu menyesuaikan dengan pemikiran suaminya dalam pendidikan Islam Moderen. Siti Walidah menyadari bahwa dirinya memiliki kewajiban yang sangat besar dalam pendidikan untuk mengentaskan kaumnya dari belenggu kebodohan. Untuk itu Siti Walidah mulai mendidik kader-kader muda bangsa melalui Media Penyelenggara internaat (pondok) khusus bagi anak perempuan. ${ }^{23}$

Konsep pemikiran pendidikan menurut Siti Walidah bahwa peempuan muslim tak hanya tahu tugas berumah tangga, tetapi juga tahu tugas mereka dalam kewajiban bernegara dan bermasyarakat. Siti Walidah mendirikan sekolah-sekolah putri dan asrama, serta keaksaraan dan program pendidikan Islam bagi perempuan. Siti walidah juga menentang kawin paksa, yang waktu itu menjadi tradisi masyarakat di Jawa. Pada tahun 1921, Siti Walidah menjadi Ketua Aisyiyah yang pertama, lewat Kongres ke 5 Aisyiyah di Jogjakarta. Pada masa awal masa kepemimpinanya, ia fokus pada kegiatan pemberian dakwah di seluruh Pulau Jawa. ${ }^{24}$

Pada tahun kedua kepemimpinannya, Siti Walidah berfokus pada pendirian masjid perempuan. Kemudian pada tahun berikutnya Siti Walidah memusatkan kegiatan organisasi kearah pendidikan keagamaan dan kursus kesehatan mental. Kemudian pada tahun 1924 Siti Walidah terpilih lagi untuk keempat kalinya. Siti Walidah memusatkan kegiatan Aisyiyah berfokus pada pendidikan formal dan nonformal. Kemudian pada tahun 1925, 1926, dan 1930 terpilih lagi sebagai ketua Aisyiyah dengan membuat terobosan baru yaitu mendirikan Majalah Suara Aisyiyah.

\section{Siti Munjiyah}

Siti Munjiyah dilahirkan pada hari senin tanggal 14 bulan dzulhijjah 1317 atau 19896 masehi, anak dari lurah Keraton Jogjakarta, haji Hasyim Ismail. Penampilannya yang sederhana tidak menunjukkan bahwa ia adalah salah satu putri lurah Keraton. ${ }^{25}$ Siti Munjiyah termasuk santri awal Kyai Haji Ahmad Dahlan. Di Madrasah Diniyah milik Ahmad Dahlan, Siti Munjiyah mendapat pendidikan langsung agama dari Kyai Haji Ahmad Dahlan melalui kursus dan pengajian yang diadakan. Setelah menyelesaikan

${ }^{22}$ Yusuf Abdullah, Perjuangan dan Pengabdian Muhammadiyah, Jakarta: Pustaka Antara, 1989, hal.

23 Bisyron Ahmadi Ranadirdja, Cikal Bakal Sekolah Muhammadiyah, Yogjakarta: Badan pembantu Pelaksana Pembantu Pendidikan Pawiyatan Wanita Sekolah Dasar Muhammadiyah,1980, hal. 80

${ }^{24}$ Dian Ardiyani, Konsep Pendidikan Perempuan Siti Walidah, Tajdida, Vol 15, No.1, Juni, Surakart: UMS, 2017, hal. 12

${ }^{25}$ Mu'arif, Hajar Nur Setyowati, Srikandi-srikandi Aisyiyah, Yogjakarta, Suara Muhammadiyah, 2014, hal. 77-85 
pendidikan di Madrasah Diniyah, Siti Munjiyah masuk kelas Qismul Arqo yang diadakan di emperan rumah Kyai Ahmad Dahlan. Qismul Arqo kemudian diganti namanya menjadi Pondok Muhammadiyah setelah menempati gedung baru dan menggunakan sistem klasikal.

Sejak terbentuk perkumpulan Sapa Tresno (1917) yang berawal dari kursus membaca Al-Quran dibawah Kiai Haji Ahmad Dahlan, para aktivis perkumpulan ini terus bertambah. Semakin banyak santri perempuan yang aktif di perkumpulan Sapa Tresno, diantara mereka adalah lulusan sekolah netral dan sekolah agama. Perempuan muda itu menjadi wakil ketua panitia, bersanding dengan R.A Sukonto, ketua panitia Kongres, sebagai wakil ketua panitia yang mewakili utusan Aisyiyah, dia mendapat kesempatan untuk berpidato, menyampaikan pandangan-pandangannya seputar kedudukan wanita dalam Islam. Setelah mendengar pidatonya, peserta konggres langsung sadar bagaimana agama Islam mendudukkan kaum perempuan. Munjiyah termasuk salah satu di antara anak-anak Haji Hasyim Ismail, lurah Keraton Yogjakarta. Dia bersaudara dengan Jasimah, Syuja', Fachrodin, Hadikusumo, Zaini, Siti Bariyah, Siti Walidah. ${ }^{26}$ Munjiyah tidak hanya piawai dalam berkhutbah, tetapi juga sebagai Dai Perempuan yang handal.

Siti Munjiyah termasuk sosok orator ulung yang mampu menguasai khalayak umum, mampu tampil sebagai perwakilan Aisyiyah dalam forum-forum perkumpulan kaum perempuan di luar Muhammadiyah dengan keahlian yg dimiliki. Siti munjiyah pernah menjadi satu satunya utusan perempuan HB Muhammadiyah yang tampil untuk menyampaikan ceramah keagamaan dalam acara Sarekat Islam pada 20 november 1921. Karakter Siti Munjiyah yang bersemangat, mampu menyihir para hadirin saat itu. Walaupun demikian dia seorang ulama perempuan yang memiliki pandangan inklusif dan toleran. Meskipun dalam pidatonya dia membela hukum Islam, tetapi dengan bahasa yang halus dia berusaha untuk tidak merendahkan agama-agama lain. Pada tanggal 22-25 desember 1928, Aisyiyah mempercayakan Siti Munjiyah untuk mewakili dalam acara Kongres Perempuan Indonesia pertama di Mataram, Yogjakarta. Pidatonya berjudul "derajat perempuan". Siti Munjiyah juga mengkritisi barat dan feminisme, ia menerangkan betapa perempuan dari kalangan non Islam terlihat tertekan karena tidak memiliki hak-hak dalam perkawinan. Berdasarkan sejarah pandangan Barat dan juga tradisi Kristen memang diskriminatif terhadap perempuan. ${ }^{27}$

\section{Nyai Khairiyah Hasyim}

Lahir di Tebu Ireng pada tahun 1906. Khoiriyah merupakan putri KH. Hasyim Asy'ari. Untuk nasab dari jalur ibunya adalah khairiyah binti Nafiqah binti Nyai Ilyas ibn Mustaram ibn Maklum ibn Muhammad Sentori ibn Basyariyah ibn Nala Jaya ibn Abdul Alim ibn Raden Panji Darma Santana ibn Paduraksa ibn Peringgalia ibn pangeran kajuruan

${ }^{26}$ Yunus Anis, Riwayat Hidup Nyai Ahmad Dahlan Ibu Muhammadiyah dan Aisyiyah Pelopor Pergerakan Indonesia, Jogjakarta: Yayasan Mercusuar, 1969, hal. 9

${ }^{27}$ Susan Blackburn, Kongres Perempuan Pertama; Tinjauan Ulang, Jakarta: Yayasan obor Indonesia, 2007, hal. xxxvii 
ibn Panembahan Senopati (Pendiri Kesultanan Mataram). ${ }^{28}$ Pada tahun 1930, membuka Madrasah Salafiyah Syafiiyah, TK Ibtidaiyah yang masih tingkatan Sifir awal dan Tsani. Perjalanan pernikahan yang dibangun dengan Kyai Maksum Ali tiba-tiba roboh. Suaminya yang begitu dicintainya wafat. Tentu menjadi pukulan berat bagi Nyai Khoiriyah Hasyim. Beliau pun menggantikan suaminya menjadi pengasuh Pesantren. Amat langka dizaman itu, perempuan menjadi pengasuh Pesantren. Pesantren Seblak dalam kendalinya, dari mulai urusan pengajian hingga pembinaan santri. Beliau juga mendirikan Madrasatul Banat ketika beliau tinggal di Makkah.yaitu sebuah Madrasah pertama di Arab Saudi yang dikhususkan bagi kaum perempuan. Intelektualitas Nyai Khoiriyah Hasyim tidak ada yang meragukan baik terhadap penguasaan terhadap Kitab Kuning, Manajemen Pendidikan, Ketrampilan dan lainnya. Di lingkungan Nahdliyin duduk di Komisi Batsul Masail. Minimnya perempuan hebat dari Pesantren, baik dari segi keilmuan dan luasnya pengalaman maka dijuluki sebagai tokoh perempuan pesantren.

Nyai Khariyah Hasyim adalah sosok ulama perempuan yang berjuang untuk menegakkan kalimat Allah serta sosok pahlawan Indonesia yang berjuang untuk memajukan derajat perempuan. Diantara pemikiran tentang konsep pendidikan perempuan yaitu; 1) kesetaraan antara perempuan dan laki-laki dalam memperoleh hak pendidikan, tidak ada dikotomi antara keduanya, 2) Menerapkan pola pikir kritis, kreatif dan aktif kepada para santri dalam menempuh proses pembelajaran, 3) Tidak ada pembagian kurikulum perempuan dan laki-laki. ${ }^{29}$ Pemikiran dan gagasan tentang konsep pendidikan Islam diimplementasikan dalam berbagai lembaga pendidikan yang didirikannya yaitu TK Khairiyah, Madrasah Tsanawiyah, Madrasah Aliyah, Sekolah Persiapan Tsanawiyah.

\section{Rahmah El-Yunusiah}

Tokoh perjuangan dan pendidikan Islam wanita dari Sumatra Barat ini, lahir di Padang Panjang pada tanggal 29 Desember 1900, dan wafat di daerah yang sama pada tanggal 26 februari 1969. Dialah pendiri Madrasah Diniyah Putri Padang Panjang pada tanggal 1 november 1923 yang merupakan Perguruan Wanita Islam pertama di Indonesia. Rahmah El-Yunusiah sangat kuat pendirianya dalam menanamkan jiwa agama di lembaga pendidikan yang dibangunnya. Agama baginya adalah dasar bagi pembentukan karakter manusia, dan menjadi inti berdirinya berbagai kegiatan lainnya, termasul bidang Politik. Rahmah berpendapat bahwa pelajaran agama itu lebih penting dari pelajaran apapun. Pelajaran agama merupakan suatu dasar untuk menilai segala masalah yang akan mereka hadapi dalam kehidupan masa depan anak-anak. Menurut Rahmah, bahwa masalah politik dengan sendirinya akan dapat diketahui oleh para pelajar pada saat mereka terlibat dalam

${ }^{28}$ Muzayyanah Hamas, 1997, Ny Hj. Khoiriyah hasyim, 1908-1983, Tinjauan Historis Tentang Pendidik dan Pejuang Emansipasi, Skripsi: IAIN Sunan Ampel Surabaya, 1997, hal. 30

${ }^{29}$ Ninda Novalia, Ulama Perempuan dan Dedikasinya dalam Pendidikan Islam ( Studi Pemikiran Nyai Khoiriyah Hasyim, Skripsi, UIN Walisongo Semarang, 2019, hal.90 
kegiatan perpolitikan. Yang penting adalah dasar Islam yang mereka terima di sekolah yang kelak akan menjadi dasar bagi upaya-upaya mereka dalam kegiatan berpolitik. Didalam gerakan politik akan dipergunakan secara bertentangan dengan kepentingan Islam apabila tidak disertai Iman.

Usaha Rahmah El-Yunusiah dalam bidang pendidikan untuk kaum wanita khususnya itu didasarkan pada cita-citanya, bahwa kaum wanita Indonesia harus memperoleh kesempatan penuh untuk menuntut ilmu yang sesuai dengan kodrat wanita, sehingga dapat diamalkan dalam kehidupan sehari-hari. Usaha pendidikannya itu ditujukan untuk kaum wanita agar sanggup berdikari untuk menjadi ibu pendidik yang cakap, aktif dan bertanggung jawab kepada kesejahteran bangsa dan tanahair. Cita-cita ini dirumuskan dalam tujuan pendirian Diniyah Putri. ${ }^{30}$ Konsepsi pendidikan Rahmah ElYunusiah didasarkan pada konsep" Pendidikan Untuk Semua”. Falsafah ini diangkat dari prinsip-prinsip yang terdapat dalam Al-Quran dan Hadis yang memposisikan manusia pada posisi yang sama. Perbedaan diantara manusia yang satu dengan yang lainnya hanya terletak pada tingkat Ketaqwaan dan Kebermaknaanya dimuka bumi.

Konsepsi ini di realisasikan Rahman el_Yunisiah dengn mendirikan Madrasah li AlBanat yang kemudian dikenal dengan nama Madrasah Diniyah Putri Padang Panjang. Tujuan Madrasah Diniyah Putri menekankan urgensi pembentukan individu dalam hubungannya dengan tanggung jawab moral dan sosial. Sementara disisi lain, Madrasah ini memiliki konsistensi terhadap ajaran Islam. Pendidikan yang diterapkan berupaya membentuk pribadi-pribadi yang memiliki keterikatan Transenden. Lembga pendidikan ini juga berupaya memberikan latihan kecakapan guna meningkatkan kreatifitas dan realisasi peran kekhalifahan manusia di muka bumi. ${ }^{31}$ Secara komprehensif, pemikiran Rahmah el- Yunisiyah terlihat jelas pada konsep 'Tri Tunggal Pendidikan Perempuan', yaitu (1) Pendidikan di Sekolah, (2) Pendidikn di Asrama, dan (3) Pendidikan di Masyarakat.

Upaya pembaharuan yang dilakukannya memalui Madrasah Diniyah Putri akhirnya dapat diterima. Penerimaan ini ditandai dengan semakin banyak permintaan dari masyarakat agar institusi ini mengirim lulusannya mengajar diberbagai daerah, bahkan sampai ke Malaysia. Melalui para alumninya, ia berhasil mengembangkan institusi penddikan yang didirikannya dengan mendirikan beberapa cabang Madrasah Diniyah Putri di Sumatra dan Jakarta. ${ }^{32}$

\section{Zakiah Daradjat}

\footnotetext{
30 Abuddin Nata, Tokoh-Tokoh Pembaharuan Pendidikan Islam di Indonesia, Jakarta: PT Raja Grafindo Persada, 2005, hal. 30

31 Samsul Nizar, Ensiklopedi Tokoh Pendidikan Islam (Mengenal Tokoh Pendidikan di Dunia Islam dan Indonesia), Jakarta: PT Ciputat Press Group, 2005, hal. 256

${ }^{32}$ Deliar Noor, Gerakan Moderen Islam, Jakarta: Logos, 1999, hal. 65
} 
Tokoh perempuan dari Bukit Tinggi yang bernama Zakiah Daradjat di lahirkan di Kampung kota Merapak, Kecamatan Ampek Angkek, Kotamadya Bukittingi pada tanggal 6 November 1929. Ayahnya bernama H. Daradjat adalah aktivis Muhammadiyah di Bukit Tinggi. Zakiah Daradjat di samping sebagai seorang Ilmuwan Psikologi Agama dan Ilmuwan dalam Pendidikan Islam juga sebagai birokrat pemerintahan dalam lingkup Kementrian Agama. Sebagai seorang ahli jiwa agama ia selalu berpegang teguh pada ajaran Al-Quran dan Al-Sunnah serta pemikiran (Ijtihad) yang tidak bertentangan dengan AlQur'an dan Hadis Nabi. Konsepsi dalam bidang pendidikan Islam amat dipengaruhi oleh keahliannya dalam ilmu jiwa agama yang berdasarkan Al-Quran, Sunnah dan Ijtihad. Jabatan terkhir yang diembannya adalah sebagai Direktur Perguruan Tinggi Agama Islam. Gagasan dan pemikiran Zakiah Daradjat dalam bidang Pendidkan Islam adalah sebagai berikut:

Pertama, hakekat pendidikan Islam yang sesungguhnya tidak hanya memperhatikan satu segi saja, aeperti aqidah, ibadah atau akhlaknya saja, melainkan mencakup seluruhnya, bahkan pendidikan Islam mencakup semua dimensi manusia. Pendidikan bersifat integralistik dan komprehensif, yaitu mencakup seluruh dimensi, eksistensi, substansi dan relasi manusia.

Kedua. Hakekat pendidikan Islam menghubungkannya dengan sifat dasar manusia sebagai makhluk yng memiliki potensi baik dan buruk. Tugas pendidikan dalam konteks ini adalah mengembangkan dan meningkatkan semaksimal mungkin potensi yang cenderung negatife dan buruk. Selain itu, pendidikan juga harus mengembangkan dimensi manusia yang terdiri dari tujuah macam: fisik, akal, iman, akhlak, kejiwaan, keindahan, dan sosial kemasyarakatan. Pendidikan harus ditujukan untuk membangun dan membina manusia yang kuat, sehat dan mampu melaksanakan tugasnya, membina fisiknya yang sehat sehingga tercipta kepribadian yang seimbang dan selaras sebagai pengabdian kepada Tuhan, membina dan mengolah fisik yang kokoh, sehingga terbina sikap-sikap terpuji seperti bersikap toleran, sportif dan kerja sama

Ketiga, sebagai seorang pembaru pendidikan pada zamanya, bisa dilihat perannya dalam melahirkan SKB Tiga mentri yang mengandung misi meningkatkan mutu pendidikan Islam serta menjadi peretas jalan bagi integrasi pendidikan Islam ke dalam sistem pendidikan nasional, upaya-upaya pembaharuan pendidikan Islam yang dilakukan Zakiah Daradjat, tampak masih cukup relevan untuk di aplikasikan di masa sekarang, terutama dari segi tujuan dan semangatnya untuk meningkatkan mutu pendidikan agama Islam. ${ }^{33}$ Upaya Lainnya yang dilakukan oleh Zakiah Daradjat adalah peningkatan mutu pegelolaan (administrasi) dan akademik madrasah-madarasah yang ada di Indonesia. Untuk di zaman ini telah muncul apa yang disebut dengan madrasah model..$^{34}$

\section{Penutup}

${ }^{33}$ Samsul Nizar, Ensiklopedi Tokoh Pendidikan Islam (Mengenal Tokoh Pendidikan di Dunia Islam dan Indonesia), Jakarta: PT Ciputat Press Group, 2005, hal. 256

34 Abuddin Nata, Tokoh-Tokoh Pembaharuan Pendidikan Islam di Indonesia, Jakarta: PT Raja Grafindo Persada, 2005, hal. 237 
112 Kontribusi Ulama Perempuan ....

Secara eksistensial, setiap manusia baik laki-laki maupun perempuan mempunyai harkat dan martabat yang sama, sehingga secara asasi berhak untuk dihormati dan diperlakukan sesuai dengan harkat dan martabatnya. Sepanjang sejarah Islam sejak masa Rasulullah Saw, ulama perempuan telah ada dan berperan nyata dalam pembentukan peradaban dan perkembangan Islam. Namun keberadaan dan perannya terpinggirkan oleh sejarah yang dibangun secara sepihak selama berabad-abad. Kehadiran ulama perempuan dengan peran dan tanggung jawab keulamaanya di sepanjang masa pada hakekatnya adalah keterpanggilan iman dan keniscayaan sejarah. Sebagai pewaris Nabi, tugas ulama perempuan bersama ulama laki-laki adalah melanjutkan misi-misi profetik, menyebarkan ilmu pengetahuan, membebaskan manusia dari sistem penghambaan kepada selain Allah, melakukan amar ma'ruf dan nahi mungkar, memanusiakan semua manusia, dan menyempurnakan akhlak mulia demi mewujudkan visi Rahmatan lil Alamin.

Dalam sejarah Islam posisi ulama perempuan telah menjadi bagian penting dalam setiap dinamika peradaban Islam, bukan hanya dalam tinjauan teologis tetapi juga fungsi sosial kemasyarakatan. Secara teologis, hal ini berawal dari sikap Nabi Muhammad SAW yang menghormati perempuan dan memberi jalan kebebasan bagi mereka. Akan tetapi, tradisi keulamaan perempuan di dunia Islam, termasuk Indonesia tidak hanya dipengaruhi oleh sikap penghormatan Nabi kepada perempuan, melainkan juga dipengaruhi oleh konteks geo-politik, budaya, dan proses asimilasi Islam dengan budaya lokal yang melahirkan tokoh-tokoh perempuan sesuai kontribusinya dalam perkembangan Islam.

\section{Daftar pustaka}

Abuddin Nata, 2005, Tokoh-Tokoh Pembaharuan Pendidikan Islam di Indonesia, Jakarta: PT Raja Grafindo Persada

Ahmad, Abd.Kadir, 2009, Ulama Bugis, Makassar: Indobis Publishing.

Al Yasa' Abubakar, 2005, Syariat Islam di Propinsi Aceh Paradigma Kebijakan dan kegiatan, Banda Aceh: Dinas syari'at Propinsi Nangroe Aceh Darussalam.

Azyumardi Azra, 2002, Biografi Sosial-Intelektual Ulama Perempuan: Pemberdayaan Historiografi dalam Jajat Burhanudin, Ulama Perempuan Indonesia, Jakarta: PT Gramedia Pustaka Utama

Bisyron Ahmadi Ranadirdja, 1980, Cikal Bakal Sekolah Muhammadiyah, Yogjakarta: Badan pembantu Pelaksana Pembantu Pendidikan Pawiyatan Wanita Sekolah Dasar Muhammadiyah,

De Graff, H.J. dan Th.G.Th.Pigeaud, 1985, Kerajaan-Kerajaan Islam Pertama di Jawa: Kajian Sejarah Politik Abad ke-15 dan ke-16. Terjemahan, Jakarta: Grafitipers

Deliar Noor, 1999, Gerakan Moderen Islam, Jakarta: Logos

Dian Ardiyani, 2017, Konsep Pendidikan Perempuan Siti Walidah, Tajdida, Vol 15, No.1, Juni, Surakart: UMS

Ilyas, husnul fahimah, 2018, Jurnal Al-Quran volume 24 no 2 Desember

Kuntowijoyo,1994, Metodologi Sejarah, Yogjakarta; Tiara Wacana 
Maria Hartiningsih, 2007, Perspektif Historiografi Feminis dalam Penulisan Sejarah, makalah disampaikan pada lokakarya Historiografi Indonesia di Yogjakarta yang diselenggarakan oleh Pusat Studi Asia Tenggara, UGM, Senin 30 Juli 2007

Mu'arif, Hajar Nur Setyowati, Srikandi-srikandi Aisyiyah, Yogjakarta, Suara Muhammadiyah

Munawir Haris, 2015, Kepemimpinan Perempuan Dalam Islam, Jurnal Studi Keislaman, Volume 15, Nomor 1, Juni

Muzayyanah Hamas, 1997, Ny Hj. Khoiriyah hasyim, 1908-1983, Tinjauan Historis Tentang Pendidik dan Pejuang Emansipasi, Skripsi: IAIN Sunan Ampel Surabaya

Ninda Novalia, 2019, Ulama Perempuan danDedikasinya dalam Pendidikan Islam (Studi Pemikiran Nyai Khoiriyah Hasyim), Skripsi.

Nurjanah Ismail, 2004, Teungku Fakinah; Profil Ulama dan Pejuan Wanita Aceh, dalam Tim Penulis IAIN Ar-Raniry, Ensikolopedi Pemikiran Ulama Aceh, Banda Aceh: Ar-Raniry Press.

Ras, J.J.1980, Tradisi Jawa mengenai Masuknya Islam di Indonesia, dalam Stokhof, W.A.L., dan Kaptein N.J.G(ed), Beberapa Kajian Indonesia dnan Islam, Kumpulan Karangan, Jakarta: INIS

Samsul Nizar, 2005, Ensiklopedi Tokoh Pendidikan Islam (Mengenal Tokoh Pendidikan di Dunia Islam dan Indonesia), Jakarta: PT Ciputat Press Group

Sri Astuti A. Samad, 2016, Peran Perempuan dalam Perkembangan Pendidikan Islam di Aceh (kajian Terhadap Kontribusi Wanita dalam Tinjauan Sejarah), Jurnal Al-Maiyyah, Volume 9 No. 2juli- Desember,

Suaidi Asyhari, 2010, Nalar Politik NU dan Muhammadiyah: Over Crossing Java Sentris, terj. Mohamad Rapik, Yogjakarta: LKis

Suratmin, 1981, Nyai Ahmad Dahlan (Proyek Inventarisasi dan Dokumentasi Sejarah Nasional), Jakarta.

Susan Blackburn, 2007, Kongres Perempuan Pertama; Tinjauan Ulang, Jakarta: Yayasan obor Indonesia

Tsabit Azinar Ahmad, 2011, Peran Wanita Dalam Islamisasi Jawa pada Abad XV, Jurnal Paramita Volume 21, Nomor 1- Januari

Yunus Anis, 1968, Riwayat Hidup Nyai Ahmad Dahlan Ibu Muhammadiyah dan Aisyiyah Pelopor Pergerakan Indonesia, Jogjakarta: Yayasan Mercusuar

Yusuf Abdullah, 1989. Perjuangan dan Pengabdian Muhammadiyah, Jakarta: Pustaka Antara

Zuhairini et al, 2008, Sejarah Pendidikan Islam, Jakarta: Bumi Aksara

Zulfa Jamalie dan Syaiful Hadi, 2009, Mengungkap Riwayat Peranan Fatimah binti Abdul Wahab Bugis dalam sejarah Pendidikan Perempuan di Kalimantan, Al-Banjari, voume 8 , nomor 2 , Juli 